\title{
NOS2P2 Gene
}

National Cancer Institute

\section{Source}

National Cancer Institute. NOS2P2 Gene. NCI Thesaurus. Code C38566.

Human NOS2P2 gene is located within 17p11.2 and is approximately $9 \mathrm{~kb}$ in length. The product is a processed pseudogene, which produces an RNA transcript but does not encode a protein product. 